\title{
Editorial
}

\section{Learning pathology: why? how? when?}

The publication of Tomorrow's doctors ${ }^{1}$ has led to major undergraduate curricular reorganisation in most UK medical schools. There has been much discussion about how much pathology we should be teaching, what methods we should be using, and where it should fit into the curriculum. With the forthcoming 1998 Higher Education Funding Council for England teaching quality assessment, we will be required to reflect on the ways in which we teach our undergraduates and to evaluate and justify our teaching methods.

\section{Why?}

"Why?" is probably the easiest question to answer. The cellular and molecular processes encompassed in basic pathology provide the basis for the understanding of clinical medicine. Pathology is a major informing discipline that links clinical medicine and basic science; therefore, it will always be a core subject in the curriculum. Clinical pathology, including the main disciplines of microbiology, immunology, haematology, and chemistry, underpin the practice of clinical medicine. Pathology is a popular subject with students because by its very nature it has an immediate relevance to the business of studying medicine.

\section{How?}

Pathology can be taught in a variety of ways: lectures, demonstrations, practical classes, seminars, and discussion groups. ${ }^{2}$ In addition, there are an increasing number of computer based programs of instruction available.

Whichever teaching methods are employed, there are some basic principles that should be adhered to. Students learn best when they are interested, can see the relevance of what they are learning, and are intrinsically motivated. ${ }^{3}$ They need feedback on how they are doing and often need guidance about the level they are expected to reach. As teachers we need to be enthusiastic and well organised. ${ }^{4}$ Introducing elements of discussion and interaction, especially through the use of clinical examples or problem solving practicals, will maintain interest and arousal. The use of visual aids, computer based programs, knowledge checking, and summarising will enhance student learning and understanding. Ritual humiliation, although memorable, does not enhance student learning. ${ }^{5}$

Pathology is a subject with a vast and ever expanding knowledge base. It is more important than ever that the pathology learnt in the undergraduate curriculum is basic and relevant, emphasising the understanding of mechanisms and principles rather than detailed facts. As students continue their medical education into postgraduate trainee years, more detailed systemic pathology will become more relevant and more appropriately learnt at that time.

In education theory, the acquisition of new knowledge depends on activation of prior knowledge and its reorganisation and elaboration, allowing it to be applied to different situations. ${ }^{67}$ How often do our clinical colleagues tell us that students do not know any pathology when they are quizzed on the wards? We can help our students to retrieve information when they need it by using clinical examples or a problem based approach. Problem based learning produces deep levels of learning and understanding and an ability to apply basic knowledge in the clinical setting. ${ }^{8}$ Assessments have a powerful effect on the way students learn, therefore, pathology assessments should test understanding and problem solving abilities rather than factual recall. ${ }^{9}$

\section{When?}

The traditional undergraduate medical curriculum, based on two years of basic science followed by three years of clinical apprenticeship, was characterised, among other things, by factual overload and an examination system that encouraged rote learning. ${ }^{16}$ Educational research has shown that this arrangement of theory before practice, abstract knowledge before concrete experience, actually hinders the ability of students to apply their basic science knowledge effectively in the clinical and diagnostic setting. This curriculum design also leads to undesirable shallow learning approaches where students go for factual recall rather than critical analysis or synthesis of knowledge ${ }^{10}$ in complete opposition to the objectives set out in Tomorrow's doctors. ${ }^{1}$

Many medical schools are currently adopting an integrated or problem based approach within which pathology is a core subject. The advantages of an integrated, problem based approach are that it allows students to study a subject and see the links with other subjects. For example, in a systems based course, students can develop a better understanding of cardiac disease if they learn physiology, anatomy, pharmacology, and pathology concurrently and see how they relate to each other. Problem based learning shows students the clinical relevance of their basic pathology at the time when they are learning it. Pathology can be taught in this way from day 1 of the undergraduate curriculum.

We have the opportunity in teaching pathology to fulfill the educational objectives set out by the General Medical Council and others, ${ }^{11}$ and to help medical students bridge the gap between basic science and clinical medicine. An interactive, problem based style of teaching within an integrated curriculum can be justified on educational grounds and is probably the best way to teach pathology. ${ }^{12}$ Multimedia and computer based teaching programs will play their part in the future.

CLAIR DU BOULAY

Department of Pathology

Level E, South Block,

Southampton General Hospital,

Tremona Road, Southampton, UK

1 General Medical Council. Tomorrow's doctors: recommendations on undergraduate medical education. London: GMC, 1993.

du Boulay C. In defence of the post mortem demonstration. $f$ Pathol 1994; 174:309-11.

3 Rogers A. Teaching adults. Oxford: Oxford University Press, 1993.

4 du Boulay C. Pathology teaching, how good are we? Dr Fox revisited [editorial]. F Pathol 1995;176:111-12.

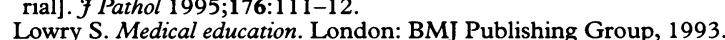

6 Schmidt HG. Foundations of problem based learning; some explanatory notes. Med Educ 1993;27:422-32. 
7 Coles CR. Elaborated learning in undergraduate medical education. Med Educ 1990;24:14-22.

Newble DI, Entwhistle NJ. Learning styles and approaches: implications for medical education. Med Educ 1986;20:162-75.

9 Newble DI, Jaeger $K$. The effect of assessments and examinations on the learning of medical students. Med Educ 1983;17:165-71.
10 Coles CR. Differences between conventional and problem based curricula in their student's approaches to studying. Med Educ 1985;19:308-9.

11 Towle A. Critical thinking. The future of undergraduate medical education. London: King's Fund Centre, 1991.

12 Benbow EW, Rutishauser S, Stoddart RW, Andrew SM, Freemont AJ. Pathologists and problem based learning. F Pathol 1996;180:340-2.

\section{Molecular Pathology-August 1997 contents}

\section{Reviews}

Phenylketonuria in Britain: genetic analysis gives a historical perspective of the disorder but will it predict the future for affected individuals?

$L A$ Tyfield

Role of platelet adhesion in homeostasis and immunopathology

D N Männel, G E Grau

\section{Papers}

A two year prospective study to compare culture and polymerase chain reaction amplification for the detection and diagnosis of Lyme borreliosis

M M Picken, R N Picken, D Han, Y Cheng, E Ruzic-Sablic, $\mathcal{f}$ Cimperman, V Maraspin, $S$ Lotric-Furlan, F Strle

Mature osteoblasts in human non-union fractures express collagen type III $D M$ Lawton, $\mathcal{f} G$ Andrew, $D R$ Marsh, $\mathcal{f} A$ Hoyland, $A \mathcal{F}$ Freemont

Proliferative activity in human glioblastomas: evaluation of different Ki67 equivalent antibodies $S H$ Torp

NO38 expression and nucleolar counts are correlated with cellular DNA content but not with proliferation parameters in colorectal carcinomas

P M De Angelis, T Stokke, O P F Clausen

Reverse transcriptase-polymerase chain reaction analysis of cytokeratin 19 expression in the peripheral blood mononuclear cells of normal female blood donors

$M$ Novaes, I Bendit, $B$ Garicochea, $A$ del Giglio

Fatty acid oxidation disorders as primary cause of sudden and unexpected death in infants and young children: an investigation performed on cultured fibroblasts from 79 children who died aged between $0-4$ years

Э B Lundemose, S Kolvraa, $N$ Gregersen, $E$ Christensen, $M$ Gregersen

\section{Technical report}

Microdissection of stained archival tissue

$S$ K Gupta, A G Douglas-fones, $f$ Morgan

\section{Short report}

A new mutation in the human lipoprotein lipase gene causing familial hyperchylomicronaemia

$R$ Anwar, $\mathcal{J} W$ L Puntis, $A$ F Markham

\section{Miscellanea}

Correspondence $\bullet$ Notice 